\title{
Contingency Plan in the Supply Chain of Companies in the Retail Industry in the Face of the Impacts of COVID-19
}

Carlos Juventino Ruiz Montoya*, José Luis Martínez Flores

UPAEP University, 21 sur 1103 Barrio de Santiago CP. Puebla, 72410, México

\begin{tabular}{l} 
A R T I C L E I N F O \\
\hline Article history: \\
Received: 01 October, 2020 \\
Accepted: 28 December, 2020 \\
Online: 05 February, 2021
\end{tabular}

Keywords:

Supply chain management

Disruptions

Risk assessment

\begin{abstract}
A B S T R A C T
The main issue that is being presented in 2020 is the impact that all organizations are having due to the COVID-19 pandemic, and it is not for less given the global collapse that is occurring in all aspects. Many organizations have been affected by this catastrophe and in the face of an unforeseen scenario, the disruptions in the different supply chains have revealed the lack of some essential products for human consumption.

For organizations that are looking for alternatives of what to do and that are constantly analyzing how to reinvent their processes to mitigate the impacts of the pandemic and thus stay current during the contingency, they have before them the challenge of strengthening their supply chains, however It is difficult to think that the contagion of this virus that has brought the great powers of the planet to their knees, collapsing their productive, economic and especially health systems.

This research aims to propose a model that allows the development of an action plan in the event of the COVID-19 contingency in the sector of companies classified as essential, such as the retail industry. It is not enough to have well-defined and structured processes, these must also be dynamic and interconnected to privilege the distribution of essential products and for this it is important to be clear about the pillars of supply chain management and the key elements that they proposed.

Organizations must learn to protect their supply chains and to achieve it research offers a perspective on how to assess the level of risk of the processes of the retail industry and thus have identified the opportunities that will have to improve to build a resilient supply chain and strengthened.
\end{abstract}

\section{Introduction}

Throughout time humanity has faced a significant number of disruptions that have affected from basic aspects such as the very survival or health of human beings to the complete collapse of the productive and economic systems, some of these disruptions have been caused for decisions related to the political and economic interests of man, such as the armed conflicts of the two world wars of the last century and that meant significant changes in the way of life of the affected countries, mainly those of the defeated side. Like the group of disruptions caused by the hand of man, there are other disruptions that have occurred and that have their origin in sometimes predictable behavior, but in many other unpredictable ones in nature, in both cases destructive, causing the loss of human lives and the destruction of assets and infrastructure for the proper

${ }^{*}$ Corresponding Author: Carlos Juventino Ruiz Montoya, cjruizmontoya@hotmail.com

www.astesj.com

https://dx.doi.org/10.25046/aj060191 functioning of business operations. In this group of natural disasters are hurricanes, earthquakes, tsunamis and fires, in addition to others, associated with diseases in humans that become epidemics and at a higher level of severity due to the size of the contagion, in the devastating effect of a pandemic.

Unfortunately, and due to this type of disruption, organizations are part of a side effect of what happens in the environment in which they find themselves. Each of these impacts and their postmortem analysis are on an undesirable list of scenarios that have already occurred at the time, such as the SARS disease that occurred in Asia from 2002 to 2003, the tsunami in Indonesia in 2004, Hurricane Katrina that The United States struck in 2005, the 2009 - 2010 H1N1 influenza that occurred in Mexico, and currently the living pandemic of the COVID-19 coronavirus that started in China and is already spread around the world in 2020. 
The historical account of disruptions that humanity has faced is wide and with a diversity of origins, however, regardless of their origin, they have something in common, a collapse of the different supply chains in the territory, region or country. where it occurs, causing to the companies a series of disorders in their supply operation from suppliers, in-house manufacturing and in the supply of goods to customers. Businesses with a more robust supply chain will enable them to be better prepared to responded more effectively to the effects of a disruption.

A service oriented organization must take care that the processes of its supply chain, in addition to being efficiently structured, have haracteristics of agility, adaptability and alignment to dynamically translate the needs that are being presented to the customer and can be respond satisfactorily in [1] the author explained the Triple A as a model that allows the supply chain to be adequately managed.

The supply chain management processes do not remain fixed over time, they have to be transformed according to the needs of the market and the sales point where the customer goes adapting to the purchasing trends of the consumer customer. Currently, from a commercial point of view in the retail industry, it is common to classify or have segmented the type of consumer that goes by store, this is a work of market intelligence, an emerging area in the modern design of organizations who have the need to know the sensitivity of how the market behaves, it is precisely this area that is responsible for doing this type of study to better define the commercial strategy to follow. In [2], the author explained the importance of having the commercial strategy integrated to the supply chain.

When talking about processes implicitly you have to consider two elements or vectors that converge on the subject, on the one hand, the capacity of the processes that in turn represent the potential designed to offer by the process, and on the other, the indicators of performance or kpi's (key performance indicators) of the processes.

To measure the performance of the processes, they must have indicators or metrics that provide feedback to the system for which they were designed. The indicators must be focused on the measurement of the operational processes and offer deliverables on what happens at the border of each process, maintain a standard of behavior that constantly aspires to excellence in performance and that are also consistent with the strategy of the organization supply chain. If the importance of the Triple A Model was previously highlighted, in [3] the author complemented the model by highlighting the importance of top management's commitment to agility, flexibility, efficiency and service. Metrics should provide feedback to the organization on the elements that make up the established strategy.

With the evolution of the supply chain, accelerated mainly by the digital era and e-commerce, organizations have focused their actions to maintain an efficient customer service process by establishing strategies that allow them to stay current in a highly competitive environment, however the backyard that integrate the supply network, the management of optimal inventories for the preparation of orders looks vulnerable or simply exposed to the risks that every organization faces in the midst of a pandemic. In [4] the author described the importance of having identified supply chain segmentation and regionalization as a way to mitigate risk. The stage during which this situation occurs generates high uncertainty where many organizations are not clear on how to act. In [5] the author explained the fact of having clear and defined processes to mitigate the effect of uncertainty and to have a clearer direction to follow by taking disruptive measures integrated in a mitigation strategy.

The purpose of this research is to offer a perspective on how to classify for a better assessment of the risk level of the retail supply chain. The classification is supported by four management pillars and these in turn integrate seven key elements that will be addressed in the proposed research methodology.

\section{Literature review}

When addressing the issue of disruptions that have occurred in the past, that are present today and that will surely continue to occur in the future, and that affect the environment where the basic daily activities of the world population are carried out, and therefore that of organizations, on this topic you can find a great diversity of research work and a multivariate approach or point of view, which depends on the type of research that the author wants to highlight or highlight. Just as these perspectives are mentioned in the different investigations carried out and that will be cited throughout the work, this investigation has as its main contribution to offer organizations an analysis, diagnosis and proposal of contingency actions against the disruptions caused by catastrophes natural as the pandemic that we are currently experiencing with COVID-19 and that affects the supply chains of companies considered or classified as essential as the retail industry, due to the impact they have on society in the supply of food and products of first necesity.

This research would not be a complete work if it does not leave a learning that generates value to the society in which companies develop and is not accompanied by a proposal for organizations on how they should be better prepared to face unplanned situations such as disruptions of this type.

Before continuing and delving into such a relevant topic today, it is important to start with a proposal to classify the disruptions that occur in organizations and in general in the society where we live, even before making such a classification it is important to be clear the definition of this, disruption is the sudden or sudden interruption of something that presents an expected behavior.

Having clarity of the definition, now if we can have a classification on the different types of disruption that exist, this classification is part of the research that has been integrated by different researchers who have contributed to their work on the subject. As described, a disruption has to do with an unexpected scenario and behavior that causes human beings, in addition to uncertainty, a forced change in their behaviors and behaviors such as work, consumption, coexistence, socialization, fun , among others. According to this description that contemplates a change in people's behavior patterns, we cannot expect something different to happen in labor and social organizations where people are the central elements that integrate them and give them life.

\subsection{Classification of disruptions affecting the supply chain}

By ordering ideas we can then say that when speaking of a disruption that affects organizations it is closely linked to an 
unexpected situation or scenario and therefore can be classified into two types of disruptions, (1) those that are in a controlled environment and that in many occasions they obey technological innovations, and (2) those that arise due to an uncontrolled situation caused by disasters or natural catastrophes and even human-induced situations without even having dimensioned the impact that this will cause, such as terrorists acts. In [6], the author explained that whatever the origin that causes a disruption brings with it impacts on the supply chain. Annex 1 shows the classification of controlled disruptive events most relevant to the retail industry.

There is, as already mentioned, another group of disruptive events that are uncontrolled and that are also worth classifying in order to have a systemic perspective of the disruptive events facing humanity. In recent years we have seen these types of incidents that affect a large part of our planet and that lead us to reflect on how to manage properly and how to be prepared to when they happen, to mention some of these incidents and their impacts, how to imagine that the eruption of a volcano in Iceland would paralyze much of Europe's air movements and with it the interruption of the flow of goods, a series of forest fires in The United States and Australia would lead to the closure of companies dedicated to the assembly of by-products or components in the United States and, in the case of Australia, the closure of companies and the displacement of the workforce to other areas of the country, the bird flu that occurred in Asia and that caused millionaire losses to many companies affected by this situation and the sanitary fence that was implemented. The hurricanes and tsunamis that have occurred in different parts of the world have caused, in addition to human tragedies, the paralysis of factories and even the complete disappearance of companies dedicated to the manufacture of inputs within different supply chains. Disruptive events caused by uncontrolled situations can be seen in Annex 2.

The focus of this research is directed to this group of disruptions in uncontrolled environments and to be more specific, to the impacts of pandemics and epidemics in supply chains, in this case to the affectation that COVID-19 is causing in the international market and in the different supply chains that integrate it, in [6] the author explained in his conceptual framework of supply chain disruptions, about disruptions in the behavior of demand and disruptions in the supply of products.

\subsection{COVID-19 and its impact on supply chains}

The effect of a pandemic like that of COVID-19 is anteceded by what happened more than two decades ago with the aforementioned $\mathrm{H} 5 \mathrm{~N} 1$ avian influenza and a few years later with the H1N1 influenza that occurred between 2009 and 2010, however, the prolonged effect by COVID -19 is unmatched in terms of economic, social and loss of life impacts.

COVID-19 has come to present itself as an evil that the present generation had not faced, it has come as a script taken from a horror movie in all aspects, a segment of the apocalypse that illustrates what the future of the world will be like after observing how the health systems of entire nations have collapsed, of the economy and not to mention the psychosocial aspect that this disease is causing. Various authors describe the current scenario using analogies that refer to a combination of interrelated variables, on the one hand the probability that it will happen and the impact that it can cause when it happens. In [7] the author metaphorically described such events as the COVID-19 pandemic as a "black swan" for humanity, in [8] the author described in reference to the same hypothesis the rarity of seeing a "black swan" and on the other hand the high impact it represents for humanity in this case the pandemic that is sweeping the whole world.

As a member of a leading transnational organization in the retail industry, just a few months ago, to be exact the beginning of 2020 , we did not imagine in our annual strategic planning process of the company the threat of facing a scenario like the one that is being presented by the effect of COVID-19, it was not a topic, much less a stage that our organization and many others imagined.

After a few months of experiencing this global collapse, it is possible to make a count of learning that has favored the operational continuity of the organizations that have remained standing to continue being a profitable option for their clients and consumers. Among these learnings we can mention some in which the research will be deepened:

1) Have a structure robust enough for management, seeking efficiency both in the execution of local operational functions and in staff functions.

2) Have an interconnected network of suppliers for each distribution center, with a solid alternative of local supply.

3) Having human resources and protecting them from the environment so that what has been previously described can take place, even becoming the most important aspect for the organization to remain current. Protecting people becomes a priority for organizations.

These three lessons help organizations have more resilient supply chains in order to get this complicated stage on track, affecting their operational continuity. The motivation to carry out an investigation to carry out this investigation is to contribute knowledge and learning in situations such as the one being experienced.

\subsection{An overview of the retail industry as an essential company in the days of COVID-19}

The COVID-19 crisis has affected the economy through different factors related to the health of the population, the mandatory blockades and interruptions to trade, as well as a series of collateral effects such as the decisions that organizations forced by the situation have had to make and which are related to maintaining sources of employment. In [9], the author explained about emotional factors such as the pessimistic feeling of consumers and companies derived from high uncertainty and financial stress.

For companies classified as essential due to the role they play before society for offering food products and other types of food considered basic for human consumption, it is a challenge to keep their supply chain processes active in a complicated environment and where many companies that are part of the supply chain gradually lose productive capacity given the situation of the pandemic and with it the available inventories. It is here at this point where presented the situation many organizations reflect on the design, the priorities and the strategy that they have followed to develop the business and where the supply chain and the supply network that integrates it become relevant, such as previously 
described, "leverage" in the factors of people, network of providers, above all the development of the premises and lastly the operational and staff structure that it provides. In [10], the author explained about the key aspect of developing collaborative strategies with suppliers and together adopting best practices that help to have a better performance in the supply chain.

The pandemic shows that it may be too simplistic to base decisions about production locations solely on economic factors and many companies may not fully appreciate their vulnerability to global shocks through their supply chain relationships and the costs this imposes. In [11], the author explains the importance of having future risk assessments of companies before they decide to relocate production or when reconsidering their location options.

There is a social commitment to the population and to the government authorities to keep the supply network in force so that the population is not affected by the lack of basic necessities. In a situation like COVID-19, a strategy must be adopted to adequately manage the shortage and make efforts to carry out emerging actions to ensure the supply of essential products. This work proposes scenarios in which organizations classified as essential, such as the retail industry, can adopt a model based on a continuity matrix in the face of the loss of capacity of the logistics network.

The value chain for food or perishable products offered in the retail industry becomes more relevant in a scenario such as the one currently presented in the COVID-19 contingency. In [12], the author described that the supply chain must be designed in such a way that production, transformation and distribution generate the expected value in the supply chain and therefore to the consumer.

\section{A structured proposal for supply chain management based on a contingency plan against COVID-19}

The proposal that is developed in this work incorporates the key elements to take care of for the operational continuity of the supply chain of companies in the retail industry. Adequate management through the proposed contingency matrix will not only allow operating with well-defined criteria for decisionmaking based on the changes that the supply chain is having in the different processes that comprise it, but will also help to maintain an organization communicated at all organizational levels about the intention of senior management in the face of the pandemic. The group of researchers who have worked on the development of the document have had the opportunity to carry out the implementation of the tool in the leading company in the market in convenience stores in Mexico.

Talking about COVID-19 today is talking about a diversity of topics that converge on a macro issue such as the global collapse due to the effects of the pandemic that we had to live in this 2020 and that will surely go beyond this year. It is common to see the large number of articles suggesting how to bring life in all aspects to a new normal.

\subsection{Method of assessing the level of risk of the supply chain}

Faced with the impacts of the pandemic, supply chains have collapsed to a greater or lesser extent throughout the world, the network of suppliers has been compromised and, in worst case scenarios, disarticulated. This level of exposure highlights the importance of having a mechanism for assessing the level of risk in the supply chain. As part of the research carried out, a method of assessing the level of risk of the supply chain is being proposed. For this, it is important to start from a statement that the authors of this work make based on the experience and consultations made in the works of other researchers. As a starting point it is necessary to start with the definition of the key, operational and service processes.

\subsection{Operational and service processes of the supply chain}

The key processes that make up the operation of the supply chain become a distinctive seal that gives identity to the organization and marks the success or failure in achieving the value proposition to the end customer.

Focused on the case of the retail industry where companies participate in an environment with some volatility and where business strategies change from one day to the next or in extreme cases, from morning to night with various promotions simultaneously and with packages or commercial combos from different suppliers, the supply chain must be directly connected to the commercial strategy in order to make each of its processes focused on providing the service work. The companies that make up the retail industry are considered essential due to the impact on the supply of food to the community where they are located.

Following are the key processes in the supply chain of a distribution center serving a network of convenience stores:

1. Supply

2. Receipt of merchandise from suppliers

3. Storage of merchandise

4. Order management and replenishment planning

5. Assortment of orders

6. Preparation and consolidation of orders

7. Loading and boarding

8. Delivery of orders to the store

The key processes of a distribution center operation can be seen in Figure 1. In [13], the author described the supply chain processes in the SCOR Model with the objective of having a valid reference for the construction of a proposal that offers visibility and focus on having an efficiency analysis of the supply chain processes. In [14], the author explained the approach to supply chain efficiency and the integration of best practices. In [15], the author contributed to the SCOR Model the hierarchy of processes for decision making and supply chain management. Table 3 shows the relationship of the proposed processes with those classified in the SCOR Model. Table 3 shows the relationship of the proposed processes with those classified in the SCOR Model.

\subsubsection{Supply}

It is the process by which all merchandise supply activities are managed from the supplier to the distribution center or directly to the stores. The supply process aims to guarantee the supply of goods in a timely manner, in the quantity required for sale and with the quality that meets the parameters of each product for sale to consumer customers. 
This process groups a series of activities considered strategic by a team that is constantly analyzing inventories, sales behavior, in close communication with the categories in which the product catalog is classified and finally with the marketing part. for proper planning of promotions.

Table 1: Comparative relationship of SCOR Model processes and operating processes of the retail industry.

\begin{tabular}{|c|c|c|}
\hline \multicolumn{2}{|c|}{ SCOR Model processes } & $\begin{array}{c}\text { Retail industry supply chain } \\
\text { operational processes }\end{array}$ \\
\hline \multirow{7}{*}{$\begin{array}{l}\text { Plan } \\
\text { Supply } \\
\text { Chain }\end{array}$} & Plan Source & Supply - Receipt of merchandise \\
\hline & \begin{tabular}{ll|} 
Source & Stocked \\
Product & \\
\end{tabular} & Storage of merchandise \\
\hline & Plan Make & Order management \\
\hline & \multirow[b]{2}{*}{ Make to stock } & Assortment of orders \\
\hline & & $\begin{array}{l}\text { Preparation and consolidation of } \\
\text { orders }\end{array}$ \\
\hline & \multirow{2}{*}{ Plan Delivery } & Loading and boarding \\
\hline & & Delivery of orders to the store \\
\hline
\end{tabular}

\subsubsection{Receipt of merchandise}

It is the reception of merchandise orders from suppliers, they obey an appointment planning agreed with suppliers and must be in accordance with procedures and policies on the requirements to be met in the proper handling of products that in some cases require certain parameters of refrigeration, humidity and security, such as the height of the platforms where the merchandise arrives.

\subsubsection{Storage of merchandise}

Within sequential flow of operations, it is the process in which the merchandise is located in a site within the area destined for storage. This process aims to create the appropriate conditions for the safekeeping and control of different goods. Each movement of merchandise from its storage location to another point, obeys a merchandise flow instruction to send said merchandise to an assortment location that can be refrigerated boxes, pieces or parts assortment.

\subsubsection{Order management}

It is an administrative process that is carried out with merchandise replacement tools at the store and is practically the equivalent of having a production program or planning of order fulfillment activities, ordered by priority based on the criticality of inventories. in shop. This process represents the intelligence center that drives the operations of the distribution center and through which resources are allocated to fulfill store orders.

\subsubsection{Assortment of orders}

It is the process in which operation personnel carry out order fulfillment activities. There are three different areas of order assortment which are:

1. Refrigerated product area: The assortment of orders is made in a plastic container and each piece is placed inside.

2. Product assortment per box area: The order assortment is for a higher unit of measure and is defined for products with high turnover or high displacement at the point of sale. To carry out this type of assortment, the Operator uses mobile equipment to place all the merchandise that is supplied per box on a pallet.

3. Product assortment area by piece, blister or minor packaging: The assortment is carried out online by assortment by pieces and the Assortment Operator uses a plastic container to place all the pieces that appear in the order of order.

After an order is filled from any assortment area, there is an assurance reliability check thread, offering feedback to the assortment team on the quality of the task performed.

\subsubsection{Preparation and consolidation of orders}

Process by which the orders already filled, both boxes and dry parts and refrigerated parts are ordered by store. It is consolidated by store and in the order in which they will be loaded in the transport unit; as well as how the orders will be delivered by store according to routing, which requires room temperature and which requires refrigeration.

\subsubsection{Loading and boarding}

Process in which the orders are loaded in the transport units according to a routing sheet and delivery order, as well as the invoicing of each order. It is important to keep a sequential control of the load so that the Distribution Operator does not have setbacks in deliveries.

\subsubsection{Delivery of orders to the store}

It is the transportation process by which the merchandise is transported and delivered from the distribution center to the store. The Distribution Operator delivers to the customer under certain conditions that have to do with product handling conditions such as maintaining the cold chain for products that require it and the corresponding administrative and control documents that support the order. Annex 3 shows the capacities of each process, as well as the associated unit of measurement.

\subsection{System of metrics or performance indicators of key processes}

As the key processes of the distribution center have been defined, each process has an associated performance standard and metrics to evaluate it. Table 5 shows the metrics for each process under the efficiency approach. In the context of the supply chain, the integration of the objectives in its different levels is an important factor for the correct selection of the indicators, which will provide a broader view of the business. In [16], the author described the importance of having identified key performance indicators, through which a reference will be available at all times to assess the resilience of the processes when a disruption occurs.

Of course, there will be other indicators that have to do with the result of the business if what you want to see is the economic contribution; however, these are more common to see throughout the chain. They are also described in Annex 5.

In order to have a level of detail that allows a better management of goods, it is essential to have an administration by product categories. In [10], the author explained the importance of interconnecting merchandise categories for efficient management of supply chain processes. Figure 1 shows the supply chain from the supplier to the store, passing through the distribution center. 


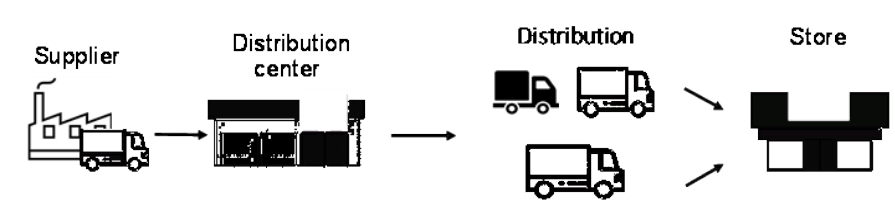

Figure 1: Supply chain from the distribution center to the convenience store (source: self made).

\subsection{Key elements to successfully respond to the COVID-19 pandemic}

During the research conducted, we had the opportunity to analyze different contributions from other researchers related to the key elements of the supply chain, which date back almost two decades. Without a framework for action that allows visibility of these key elements, it will be difficult to promote the improvement of supply chain performance. In [17], the author explained the importance for organizations of designing an operating model that facilitates the management of supply chain processes and identifying their restrictions, in addition to these elements. There are other researches that based on their studies make another proposal from a different perspective, where a classification is made according to the relevant aspects of supply chain resilience. In [18] the author presented a proposal to categorize resilience actions using four main categories: systems, process, control and recovery.

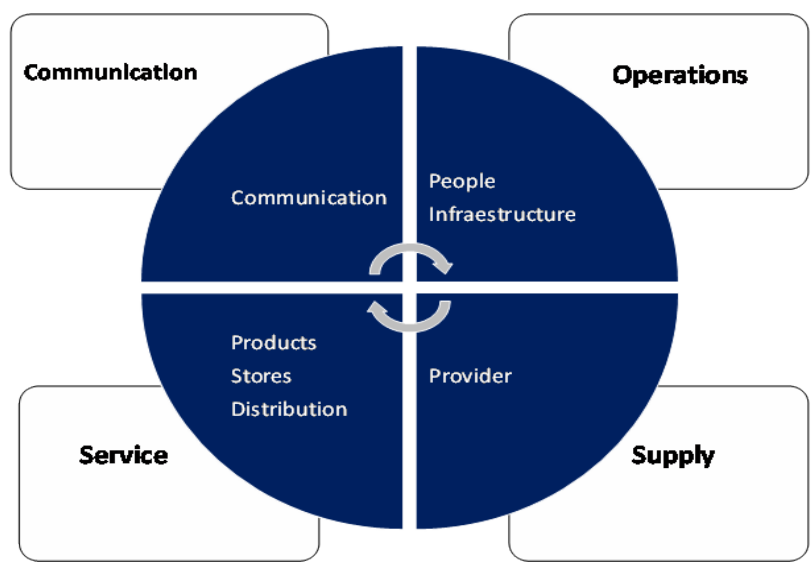

Figure 2: Key elements of the convenience store supply chain (source: self made)

The research proposal is contained in seven key elements, classified in turn into four supply chain management pillars comprising the proposed evaluation method, as shown in Figure 2. The key elements to consider in order to have A perspective and reference of the level of vulnerability of the supply chain to possible risks are grouped into four management pillars are described below:

- Operations: Refers to the group of activities that allow the continuity of the operation of the key processes. It includes the human resource, infrastructure and general facilities of the work unit.

- Supply: Includes the relationship and development of suppliers to guarantee the supply of goods from the supplier's facilities to the distribution center.

- Service: They are all the activities that allow the supply of goods from the distribution center to the store. The elements www.astesj.com that make up the service pillar are merchandise, distribution and stores.

- Communication: Refers to the strategy that the company intends to carry out to communicate its intention at all levels of the organization and even outside of it.

The key elements that, in turn, make up the supply chain management pillars and through which an evaluation of the level of response to the effects of a pandemic such as COVID-19 can be made are:

\section{People}

2. Facilities and infrastructure

3. Suppliers

4. Goods / Products

5. Stores / points of sale

6. Distribution / delivery to store

7. Communication

\subsubsection{People}

It comprises the most important resource at all levels of the supply chain, its well-being is a priority so that each of the supply chain processes can be carried out. Although it sounds like a very repeated cliche, "people are the most important thing" and they should know it and they should feel it, without a clear pronouncement from the organization of approach to people, it is difficult to advance in the other aspects.

Faced with a situation such as that of COVID-19, where the level of risk of contagion is present, there must be a consistency in the saying, in the being and in the doing from top management to the most basic positions in the structure. If there is no legitimate concern for the safety and health of people, there is no emotional bond that generates commitment.

\subsubsection{Facilities and infrastructure}

They are the assets of the organization necessary for the work units to be active. This element is closely related to human resources and must offer security and protection conditions so that personnel can carry out their activities without any distraction. It includes the industrial building or warehouse, the machinery and peripheral work equipment so that people can carry out their functions.

In the face of a pandemic like the one presented by COVID19 , maintaining the safety of the facilities becomes critical for the continuity of the operations of the companies that handle food and perishable products and that is why they are considered essential companies for society. Keeping the workplace pollution-free for employees represents a major challenge for companies and largely depends on the implementation of sanitation measures and / or protocols and strict compliance with government requirements for the preservation of hygiene standards.

\subsubsection{Suppliers}

It is the active network of suppliers that supply goods to the distribution centers or directly to the points of sale. It is important to have full knowledge of the conditions of each supplier in the 
network, in [19], the author described the importance of having information from upstream suppliers several levels back. Companies that do not do so are less able to respond or estimate the potential impacts when a crisis erupts. Under the supply chain perspective, the objective is to maintain continuity in the supply of products in order to have them in a timely manner and in the quantity required in distribution centers and / or in stores or points of sale. A supply chain is as strong as is the capacity of alternative suppliers. Some researchers consider the supplier network as the benchmark to determine the level of resilience of the companies' supply chain, highlighting as a strategy the development of local suppliers to mitigate the risk of dependence on suppliers located outside their geographical area, of the country and even to the continent.

It should be borne in mind that in the face of a pandemic such as this one, companies must develop new supply alternatives, it is a fact that the companies that precede the chain will be affected in their operations.

\subsubsection{Goods / products}

Refers to the active catalog of items offered to the customer at the point of sale. When speaking of merchandise or articles, it is important to mention that the companies dedicated to the sale of basic necessities use for a better administration of these, a classification regularly called category. This classification consists of grouping the type of merchandise so that a group of people, regularly on a staff basis, can establish the marketing strategy that involves the relationship with suppliers, marketing, study of new developments and promotion plans. The categories together with the financial area determine the profit margin of each product to evaluate its performance, establishing for this purpose negotiations of costs and sale prices. In [20], the author explained the existence of algorithms or models that allow setting price points considering the market and the position as leader in the competition.

Faced with a situation such as COVID-19, organizations must be clear about the economic performance of each product, this will allow them to make better decisions about the profitability of the business and thus privilege the items that in their classification are considered essential for society but that are also profitable for the organization. In [21], the author explained the strategy of increasing inventories can be a measure to mitigate the risk posed by a disruption, however, it is reactive to an actual shortage; the strategy can include product substitution or back-up supply.

\subsubsection{Stores / points of sale}

These are the points of sale to the consumer customer or stores that the company has. They can be classified according to their location and format by the type of customer who regularly comes to buy. In [22], the author described that the complexity of the store as such lies in the number of stores in operation and the store formats it has with different sizes, catalog and price points.

The commercial and marketing team are the ones who carry out this classification of stores and thus be able to establish a catalog of products for each type of store. This classification of stores allows in addition to establishing a catalog of particular products, establishing the entire campaign of promotions, prices and launches, this differentiation is key to evaluating the performance of each store in its sales volume.
An example of differentiation in the classification of stores is the store that is located inside a high-density residential subdivision with the store that is located inside a hospital, it will be found that neither catalog of products for sale is the same and due to the location conditions, nor is the sale income.

\subsubsection{Distribution or delivery to store}

It is the transportation process by which the merchandise is delivered from the supplier or distribution center to the point of sale. The transport equipment used is conditioned for handling both merchandise that requires refrigeration and room temperature.

Under the store delivery conditions required in this contingency stage, the distribution personnel must have the necessary protective equipment to carry out the merchandise delivery tasks at the point of sale, as well as the sanitation measures for the units must be in accordance with certain regulatory measures for the handling of perishable product.

\subsubsection{Communication}

They are the means or mechanisms established by the organization to maintain timely and assertive communication at all levels of the organization, and even in the event of possible communication with the press and / or a statement to government authorities. Communication must at all times be reliable, truthful and above all timely about the organization's intentions in the face of the contingency it is facing.

There are different methodologies that help organizations to be prepared to face a contingency from the point of view of information management and what they want to communicate from a $360^{\circ}$ perspective, as described above. We will mention that there is a methodology that helps coordinate and this is Incident Management and Crisis Resolution (IMCR), methodology developed in the United States.

\subsection{Scenarios taken to a continuity actions matrix of COVID-19}

Organizations are facing an unprecedented global crisis, human survival depends on essential elements during the pandemic and that can be met by properly utilizing key resources such as raw materials, employees and active logistics systems. In [23], the author described that the priority of nations during the pandemic is to save human lives, but shortages of essential commodities such as food, drugs, diagnostic equipment, clinical healing and personal protective equipment have made it difficult to fight the infection.

Having defined the priorities of nations and organizations to preserve the health of people as the most important priority, it remains for organizations to resolve the most important aspects to ensure the operational continuity of businesses, in [24], the author explained the importance of uncertainty management in the supply chain and how strategies can be established in inventory management. In [25], the author described that organizational leaders must urgently implement short-term strategies to be more resilient while making longer-term considerations that will reconfigure supply chains to protect against risks.

- Develop visibility of the entire value chain in primary, secondary and even tertiary players. 
- Evaluate nearby options to shorten supply chains and increase proximity to customers.

- Take advantage of advanced manufacturing technologies to be more resistant. Another important point is to systematically evaluate the end-to-end value chain, to establish agile action plans.

Organizations are facing an unprecedented global crisis, and one approach that has not exactly been the most appropriate for supply chain management is to think about generating efficiencies and savings at the expense of eliminating slack or "margins of maneuver", such as operating with a diversity of suppliers for the same product, operating with safety inventories in the chain, etc., which in the face of a disruptive situation such as the COVID-19 pandemic leaves the organization exposed. In [26], the author explained that there has long been a focus on making the supply chain more efficient based on reducing costs, reducing inventories and increasing asset utilization, thus eliminating buffers and flexibility to absorb disruptions.

With the description of the key elements and their classification by management pillar, a continuity actions matrix can be integrated in a more practical way to evaluate possible scenarios and trigger actions focused on ensuring supply to stores.

In summary, after presenting the key elements for business continuity in companies classified as essential (and largely applicable to non-essentials as well), organizations will need to work on:

- Guarantee that people feel protected in a work environment that complies with the conditions and measures of control, sanitation and use of personal protective equipment that mitigates the risk of contagion, also keeping facilities and work tools under a protocol frequent cleaning. In [19], the author explained that employee welfare is paramount, and obviously people are a critical resource.

- Developing local suppliers for the supply of key merchandise, that implies redesigning the supply network to a great extent. If COVID-19 has revealed anything, it is the high level of risk represented by having a large number of suppliers in one place.

- Organizations should develop suppliers close to their main markets; this strategy will help mitigate the risk of centralized dependence, which can be maintained and alternatively explore other sources of supply. In [4], the author explained that another important factor to consider is that as transportation and other costs increase, global supply chains may be replaced by regional supply chains.

- Provide the service as far as the contingency allows and maintain the value proposition of the stores, without infringing the care of the workers and complying with the requirements established by the government agencies. As organizations considered essential, those products of first necessity for the population must be privileged and, on the other hand, they also represent a greater profitability for the organization, for this it is important that a detailed analysis of those products is made and that level is established with suppliers. priority in supply.
- Maintain communication at all levels of the organization about the decisions that the company is taking, from issues of personnel health and care of facilities $\}$, to those that could be more critical as partial closure of operations and in in the worst case, the total closure of work units.

- For people, it is important to be informed about how the organization is facing the pandemic and what decisions are being made by senior management. To the extent that there is clear communication, the uncertainty will be combated and the staff will be focused on their care and the performance of their tasks.

- Assessing the level of risk in the supply chain is to have a preventive approach and it must be considered from the strategic planning process of organizations, that annual exercise that most organizations that describe themselves as preventive and that base their management under procedures and well-defined work systems, should consider in such planning an assessment of the risk level of their supply chain. Does this evaluation require an expense to be considered in the annual budget? The answer is yes, and excess spending due to not having an action plan to mitigate risks in the face of a disruptive event such as this pandemic may be much higher than the cost of a supply chain assessment.

- There will be many lessons learned from this disruption by COVID-19, even some organizations will not survive in order to capitalize on the learning it leaves. For the surviving companies it will be an opportunity to integrate the knowledge acquired and the recommendations that lead them to strengthen their processes and increase their resilience in the face of a disruptive event that submitted their performance and put their permanence at high risk.

The proposal made in this research is the COVID-19 business continuity matrix and is intended to provide a complete picture for organizations to evaluate the variables faced by organizations. In [27], the author described that robust strategies must be developed that integrate the purposes of reducing costs and improving customer satisfaction during and after a major disruption. In [28], the author described the importance of the design of the supply chain conceptual framework and the essential elements that have to do with resilience to disruptions that occur and supply chain resilience recovery policies. In [29], the author explained that the problem for top management of organizations is to choose a good strategy and quantify the benefits to develop a robust model for supply chain disruption analysis, for this it is important to identify and understand the overall behavior and intrinsic weaknesses of these systems and their components, especially in the face of negative events such as disruptions. In [30], the author presented that only a small minority of companies that invested in mapping and measuring the vulnerability of their supply chains are the best prepared to face this pandemic. Annex 5 shows the matrix of continuity actions to face the different impact scenarios of COVID-19.

\subsection{Stabilization of the post-disruption operation}

The stabilization stage of the operation is a continuation of the actions described in the continuity actions matrix as part of a plan where the regeneration or recovery of the resources of the supply 
chain is taking place through the effect of the disruption has yielded. It is important to prepare a recovery plan and periodically review it by the management team so that the scenarios that require decision-making are updated. To the extent that there is an updated plan and communicated to the entire organization, the horizon will be visible when a total restoration of the organization and its supply chain will be presented and thus decisions can be made as to decide when to stop buying, when to stop transporting or when to stop producing, among other operations that have had to be implemented with an over cost justified by the disruption.

Another important aspect mentioned in the key elements is the communication that exists at all levels of the organization and which must be used to reach the collaborators with what they need to know, having a single source of information helps maintain the credibility of people when their health and that of their families is at stake.

Any action plan focused on treatment, solution or simply trying to coexist with a problematic situation, in this case a disruption of natural origin, must leave knowledge to organizations, considered essential or non-essential, if organizations do not learn from these lessons they will not have the opportunity to leave a legacy and an $\mathrm{ABC}$ of what was done as good practice to come out in front of a pandemic like that of COVID-19 and new managers, they will not be able to learn from those experiences to face the new challenges that they will surely have during their management when new disruptions arise.

Among the relevant contributions that integrate the research is a series of strategies that help stabilize operations and that focus on the objectives of identifying the level of risk in the supply chain, adequately managing resources and having an action plan to mitigate risks with suppliers and internal processes. In [31], the author explained that actions should be taken to improve internal capabilities, prepare inventory levels that meet projected sales and reserve logistical capacity.

\section{Conclusions}

The importance of having defined and structured processes for proper management of the supply chain offers a scenario that helps to better manage uncertainty and for this reason to mitigate disruptive environments that arise. Having performance metrics aligned to the strategy and capabilities of the processes help not to fall into the obsolescence of the supply chain. The processes and their metrics make it easier to be able to develop a proposal that allows evaluating the level of risk in the supply chain and consequently developing an emerging action plan for each scenario that presents a disruption of the magnitude of COVID-19.

Many organizations must be sensitive to the fact that the supply chain is a series of processes that have life and that must be evaluated periodically from the perspective of the level of risk to which they are exposed due to the dynamism of environmental variables. It will always be a successful and strategic alternative to diversify the sources of resources and related to this point, these types of decisions are what organizations must bear in mind when it comes to making decisions to pulverize the supply of goods from suppliers located in another region, in another country or even on another continent.
This research aims to offer a point of reference that allows evaluating the supply chain of organizations in the retail industry, from the perspective of the key elements raised throughout the work and that in the end is the main contribution that is made.

Finally, a supply chain oriented to service and to a value proposition committed to the customer allows creating a virtuous cycle to reinvent the increasingly resilient and anti-fragile supply chain. It is important to recognize that there are different investigations that focus on the management of disruptive stages in organizations, as well as these extremely valuable work carried out, there will be other future contributions that will come with new approaches and other variables to consider. Given this scenario, there is the commitment of those who collaborated in this scientific work to leave a documented learning for future generations of how to handle these disruptions, we will not be fulfilling a professional commitment, nor would our legacy be complete on how it was managed and left ahead of COVID-19.

\section{Conflict of Interest}

The authors declare no conflict of interest.

\section{Acknowledgment}

Thanks to the companies that provided the time and information for the development of this work. Thanks to the Graduate Management in Logistics and Supply Chain Management of UPAEP University for the support in always seeking improvement in what we do.

\section{References}

[1] H.L. Lee, "The Triple-A Supply Chain". Harvard Business Review, 102-112, 2004.

[2] U. Jüttner, M. Christopher, J. Godsell, “A strategic framework for integrating marketing and supply chain strategies," Cranfield University, UK. 21 (1), 104-126, 2010, DOI: 10.1108/09574091011042205.

[3] C. Chandra, J. Grabis, "Supply Chain Configuration: Concepts, Solutions and Applications", Springer Science + Business, 2016.

[4] S. Chopra, M. S. Sodhi, "Reducing the risk of supply chain disruptions," MIT Sloan Management Review, 55 (3), 72-80, 2014. https://www.researchgate.net/publication/271853432.

[5] K. Stecke, S. Kumar, "Sources of supply chain disruptions, factors that breed vulnerability and mitigating strategies", University Texas School of Management. Journal of Marketing Channels, 16, 193-226, 2009, DOI: $10.1080 / 10466690902932551$.

[6] B. Shen, Q. Li, "Market disruptions in supply chain: a review of operational models," Donghua University Shanghai, China. International Transactions in Operational Research 2017, 697-711, 2017. DOI: 10.1111/itor.12333.

[7] N. Taleb, "The black swan the impact of the highly improbable," https://www.researchgate.net/publication/46763446_The_Black_Swan_The Impact of the Highly Improbable, 2010

[8] $\overline{\mathrm{S}}$. Zwick, "Coronavirus is bad, but the green swan is worse," https://www.ecosystemmarketplace.com/articles/coronavirus-is-dangerousbut-the-green-swan-is-worse/, 2020.

[9] M. Meier, E. Pinto, "COVID-19 Supply chain disruptions," Universität Mannheim, Department of Economics. 2020.

[10] S. Ganesan, G. Morris, J. Sandy, R. W. Palmatier, B. Weitz, "Supply chain management and retailer performance: Emerging trends, issues, and implications for research and practice," University of Arizona. Journal of Retailing 85, 84-94, 2009. doi:10.1016/j.jretai.2008.12.001.

[11] A. Serig, H. Görg, S. Mösle \& M. Windisch, "COVID-19: Disruptions on the global value chain," https://www.weforum.org/agenda/2020/04/covid-19. pandemic-disrupts-global-value-chains/, 2020.

[12] R. Zhong, L. Wang, "Food supply chain management: systems, implementations, and future research," University of Auckalnd, New Zeland. Department of Mechanical Engineering, 117 (9), 2085-2114, 2017. DOI 10.1108/IMDS-09-2016-0391. 
[13] P. Bolstorff, R. Rosenbaum, "Supply chain excellence: a handbook for dramatic improvement using the SCOR Model," Amacom, 2003.

[14] G. Reiner, P. Hofmann, "Efficiency analysis of supply chain processes," Vienna University of Economics and Business Administration, 44(23), 50655087, 2006. DOI: $10.1080 / 00207540500515123$.

[15] S. Huan, S. Sheoran, G. Wang, "A review and analysis of supply chain operations reference (SCOR) Model," University of Cincinnati, 9 (1), 23-29, 2004. DOI: 131139-158098434138188.

[16] A. Karl, J. Micheluzzi, C.R. Pereira, "Supply chain resilience and key performance indicators: a systemic literature review," Universidade do Estado de Santa Catarina, Joinville, SC, Brasil. 28, 2018. DOI: 10.1590/01036513.20180020.

[17] H. Min, G. Zhou, "Supply chain modeling: past, present and future," University of Lousville. Computers \& Industrial Engineering, 43, 231-249, 2002. PII: S0360-8352(02)00066-9.

[18] M. M. Queiroz, D. Ivanov, A. Dolgui, S. Fosso Wamba, "Impacts epidemic outbreaks on supply chain: mapping research agenda amid the COVID-19 pandemic through a structured literature review," Operationes Research. 2020. doi.org/10.1007/s10479-020-03685-7.

[19] J. B. Rice, "Prepare your supply chain for coronavirus," https://hbr.org/2020/02/prepare-your-supply-chain-for-coronavirus. 2020

[20] K. Chen, T. Xiao, "Demand disruption and coordination of the supply chain with a dominant retailer," Nanjing University, Jiangsu, China. 197, 225-234, 2009. doi:10.1016/j.ejor.2008.06.006.

[21] L. V. Snyder, A. Zümbül, P. Peng, Y. Rong, A. J. Schmitt, B. Sinsoysal, "OR/MS Models for supply chain disruptions: a Review," University of Nebraska, USA, 2015. DOI: 10.1080/0740817X.2015.1067735.

[22] E. Ekinci, A. Baykasoglu, "Modelling complexity in retail supply chains," Dokuz Eylul University, Izmir, Turkey. 45 (2), 297-322, 2016. DOI 10.1108/K-12-2014-0307.
[23] S. Singh, R. Kumar, R. Panchal, M. Kumar Tiwari, "Impacto of COVID-19 on logistics systems and disruptions in food supply chain," National Institute of Industrial Engineering (NITIE), Mumbai, India. International Journal of Production Research, DOI: 10.1080/00207543.2020.1792000, 2020.

[24] S. Chopra, P. Meindl, "Supply chain management: strategics, plan and operations," Pearson 2013.

[25] F. Betti, Kristian Hong, "Coronavirus is disrupting global value chains. Here's how companies can respond," https://www.weforum.org/agenda/2020/02/howcoronavirus-disrupts-global-value-chains. 2020.

[26] J. Kirkpatrick, L. Barter, "COVID-19 Managing supply chain risk and disruption," https://www2.deloitte.com/global/en/pages/risk/articles/covid19-managing-supply-chain-risk-and-disruption.html, 2020.

[27] C. Tang, "Robust strategies for mitigating supply chain disruptions," UCLA Anderson School, 9 (1), 33-45, 2006. DOI: 10.1080/13675560500405584.

[28] D. Ivanov, A. Dolgui, B. Sokolov, M. Ivanova, "Disruptions in supply chain and recovery policies: state of the art review," Berlin School of Economics and Law, Berlin, Germany, 49 (12), 1436-1441, 2016. 10.1016/j.ifacol.2016.07.773.

[29] M. F. Blos, P. F. Miyagi, "Modeling the supply chain disruptions: a study based on the supply chain interdependencie," Escola Politecnica da Universidade de Sao Paolo, SP, Brazil, 48 (3), 2053-2058, 2015. 10.1016/j.ifacol.2015.06.391.

[30] T. Choi, D. Rogers, B. Vakil, "Coronavirus is a wake-up call for supply chain management," https://hbr.org/2020/03/coronavirus-is-a-wake-up-call-forsupply-chain-management, 2020.

[31] D. Simchi-Levi, "Three scenarios to guide your global supply chain recovery, Even as the business climate remains deeply unpredictable, supply chain leaders should act now to plot their comebacks," https://sloanreview.mit.edu/article/three-scenarios-to-guide-your-globalsupply-chain-recovery/, 2020.

Annex 1. Main disruptive events in a controlled environment in the retail industry.

\begin{tabular}{|c|c|}
\hline Disruption & Description \\
\hline Technological effect / e-commerce & $\begin{array}{l}\text { Definitely the disruptive element with the greatest impact in the last } \\
\text { decade, those who dominate networks and online shopping have ample } \\
\text { possibilities to position themselves in a highly competitive market. Today } \\
\text { it is a must for organizations to be in the online market. }\end{array}$ \\
\hline $\begin{array}{l}\text { Proximity, time dedicated to home } \\
\text { purchase and delivery }\end{array}$ & $\begin{array}{l}\text { Another disruptive element associated with the first, the famous last mile } \\
\text { represents for the consumer customer a key decision factor to carry out } \\
\text { the purchase. Delivering merchandise at the consumer's door is a battle } \\
\text { that is being waged every day today. }\end{array}$ \\
\hline Specialty market and lifestyle & $\begin{array}{l}\text { Not all stores have the same product catalog, for different reasons or } \\
\text { circumstances, the store's commercial design may change to serve certain } \\
\text { types of customers who come to or are in that market. A convenience } \\
\text { store located in a popular sector should have a differentiation from a store } \\
\text { located in a university. }\end{array}$ \\
\hline Catalog of products and services & $\begin{array}{l}\text { With the passage of time the convenience store has become a strong } \\
\text { competitor for large supermarkets, let's say that the evolution of the } \\
\text { "corner store" has become a convenience store that offers the consumer } \\
\text { customer a wide catalog of products and services. }\end{array}$ \\
\hline Perishable management & $\begin{array}{l}\text { Bet on handling products that require refrigeration such as prepared food, } \\
\text { meat and fruits and vegetables. Even a growing market that procures } \\
\text { organic products claims a segment for this type of product. }\end{array}$ \\
\hline
\end{tabular}


Annex 2. Main disruptive events in an uncontrolled environment in the retail industry.

\begin{tabular}{|l|l|}
\hline \multicolumn{1}{|c|}{ Disruption } & \multicolumn{1}{c|}{ Description } \\
\hline $\begin{array}{l}\text { Natural disasters such as earthquakes, } \\
\text { hurricanes, tsunamis, volcanic } \\
\text { eruptions, fires, among others. }\end{array}$ & $\begin{array}{l}\text { Natural events that happen suddenly in different locations in the world } \\
\text { and that cause a collapse in the flow of goods and in the economic aspect. } \\
\text { Although they may be areas that have identified the level of risk, this type } \\
\text { of natural disaster cannot be forecast. }\end{array}$ \\
\hline $\begin{array}{l}\text { Pandemics / epidemics and other health } \\
\text { issues involving a sanitary fence }\end{array}$ & $\begin{array}{l}\text { Condition where the health of the population of a country or countries } \\
\text { that have a commercial relationship is affected by the exchange of goods } \\
\text { among themselves. The effect of a global pandemic has an impact on the } \\
\text { flow of goods of all the countries that are interconnected for the transfer } \\
\text { of goods and other types of resources. }\end{array}$ \\
\hline Terrorist acts & $\begin{array}{l}\text { Premeditated or intentional actions that aim to cause destabilization } \\
\text { through inflicting damage to a specific place or society and that through } \\
\text { chaos there is an expected size of affectation. In general, the disruptive } \\
\text { event that it causes has to do with reinforcing security measures and trade } \\
\text { blockades. }\end{array}$ \\
\hline Socio-political and economic decline & $\begin{array}{l}\text { Aggravation of the socio-political conditions of a country which causes a } \\
\text { recession or deceleration in the economic development of the industry } \\
\text { and in general for the population. This type of disruption can take time to } \\
\text { appear at the maximum level of affectation and as it is a slow process, it } \\
\text { also usually takes time to mitigate the level of maximum affectation. }\end{array}$ \\
\hline Armed conflicts & $\begin{array}{l}\text { Like the disruptions considered as deterioration of the social and political } \\
\text { fabric and as a consequence an adverse economic impact, in many cases } \\
\text { society ends up rising up in arms before an unacceptable government. } \\
\text { This type of disruption often takes a long time to find a solution that } \\
\text { manages to offer social and economic stability. }\end{array}$ \\
\hline
\end{tabular}

Annex 3. Operational and service processes of a retail industry supply chain.

\begin{tabular}{|c|c|c|c|}
\hline Processes & Capacity & $\begin{array}{c}\text { Unit of } \\
\text { measurement }\end{array}$ & Description \\
\hline \multirow{3}{*}{ Supply } & Active code catalog & $\begin{array}{l}\text { No. active } \\
\text { codes }\end{array}$ & It is the catalog of active product codes. \\
\hline & Active providers & $\begin{array}{l}\text { No. of active } \\
\text { providers }\end{array}$ & The number of active suppliers supplying merchandise. \\
\hline & $\begin{array}{l}\text { Supply service for } \\
\text { criticality of merchandise } \\
\text { and supplier }\end{array}$ & $\%$ service level & $\begin{array}{l}\text { It is the level of supply service that can be measured } \\
\text { according to the criticality by merchandise and by supplier. }\end{array}$ \\
\hline $\begin{array}{l}\text { Merchandise } \\
\text { reception }\end{array}$ & Merchandise reception & Pallets & Pallets received from the supplier. \\
\hline \multirow{6}{*}{$\begin{array}{l}\text { Storage } \\
\text { merchandise }\end{array}$} & Case storage positions & Pallets & Number of positions for storing product pallets in cases. \\
\hline & Case assortment positions & Pallets & $\begin{array}{l}\text { Number of positions for product pallets that will be } \\
\text { supplied by cases. }\end{array}$ \\
\hline & Dry parts storage positions & Pallets & $\begin{array}{l}\text { Number of positions for storing product pallets in boxes. } \\
\text { Shares storage with group of cases. }\end{array}$ \\
\hline & $\begin{array}{l}\text { Dry pieces assortment } \\
\text { positions }\end{array}$ & $\begin{array}{l}\text { Assigned } \\
\text { positions / } \\
\text { lanes }\end{array}$ & $\begin{array}{l}\text { Number of positions fed by cases and to be supplied by } \\
\text { pieces. }\end{array}$ \\
\hline & $\begin{array}{l}\text { Refrigerated parts storage } \\
\text { positions }\end{array}$ & Pallets & $\begin{array}{l}\text { Number of positions for storing product pallets in } \\
\text { refrigerated product cases. }\end{array}$ \\
\hline & $\begin{array}{l}\text { Refrigerated parts } \\
\text { assortment positions }\end{array}$ & $\begin{array}{l}\text { Assigned } \\
\text { positions / } \\
\text { lanes }\end{array}$ & $\begin{array}{l}\text { Number of positions fed by boxes and to be supplied by } \\
\text { refrigerated pieces. }\end{array}$ \\
\hline
\end{tabular}


C. Ruiz et al. / Advances in Science, Technology and Engineering Systems Journal Vol. 6, No. 1, 819-832 (2021)

\begin{tabular}{|c|c|c|c|}
\hline \multirow{3}{*}{$\begin{array}{l}\text { Order } \\
\text { management }\end{array}$} & $\begin{array}{l}\text { Assortment of cases on } \\
\text { shift }\end{array}$ & Cases & $\begin{array}{l}\text { Capacity considered for planning and assigning tasks of } \\
\text { assortment cases. }\end{array}$ \\
\hline & $\begin{array}{l}\text { Assortment of pieces dry } \\
\text { pieces on shift }\end{array}$ & Pieces & $\begin{array}{l}\text { Capacity considered for planning and assigning dry parts } \\
\text { assortment tasks. }\end{array}$ \\
\hline & $\begin{array}{l}\text { Assortment of refrigerated } \\
\text { parts on shift }\end{array}$ & Pieces & $\begin{array}{l}\text { Capacity considered for planning and assigning chilled } \\
\text { parts assortment tasks. }\end{array}$ \\
\hline \multirow{3}{*}{$\begin{array}{l}\text { Assortment of } \\
\text { orders }\end{array}$} & $\begin{array}{l}\text { Assortment of cases on } \\
\text { shift }\end{array}$ & Cases & $\begin{array}{l}\text { Assortment capacity per shift of the assortment staff of } \\
\text { boxes assortment. }\end{array}$ \\
\hline & $\begin{array}{l}\text { Assortment of dry pieces } \\
\text { on shift }\end{array}$ & Pieces & $\begin{array}{l}\text { Assortment capacity per shift of operating personnel for } \\
\text { assorting dry parts. }\end{array}$ \\
\hline & $\begin{array}{l}\text { Assortment of refrigerated } \\
\text { parts on shift }\end{array}$ & Pieces & $\begin{array}{l}\text { Assortment capacity per shift of assorted operating } \\
\text { personnel for refrigerated parts. }\end{array}$ \\
\hline \multirow{2}{*}{$\begin{array}{l}\text { Preparation and } \\
\text { consolidation } \\
\text { of orders }\end{array}$} & $\begin{array}{l}\text { Lowing of containers } \\
\text { (pieces) }\end{array}$ & Containers & $\begin{array}{l}\text { Number of drops for containers that were supplied by dry } \\
\text { pieces. }\end{array}$ \\
\hline & $\begin{array}{l}\text { Preparation of pallets on } \\
\text { duty }\end{array}$ & Pallets & $\begin{array}{l}\text { Number of pallets prepared in the convergence of the } \\
\text { assortment of dry pieces and cases. }\end{array}$ \\
\hline \multirow{2}{*}{$\begin{array}{l}\text { Loading and } \\
\text { boarding }\end{array}$} & Staying of prepared pallets & Pallets & $\begin{array}{l}\text { Ability to safeguard assorted orders waiting to be loaded } \\
\text { on the platform. }\end{array}$ \\
\hline & Pallet load per hour & Pallets & $\begin{array}{l}\text { Loading capacity to transport units associated with mobile } \\
\text { equipment movements. }\end{array}$ \\
\hline \multirow{2}{*}{$\begin{array}{l}\text { Delivery of } \\
\text { orders to store }\end{array}$} & Transport fleet & No. of units & Transport units that make up the vehicle fleet. \\
\hline & Gates & $\begin{array}{c}\text { No. of loading } \\
\text { gates }\end{array}$ & $\begin{array}{l}\text { Number of platforms enabled for loading and unloading } \\
\text { operations. }\end{array}$ \\
\hline
\end{tabular}

Annex 4. Key performance indicators of supply chain processes.

\begin{tabular}{|c|c|c|c|}
\hline Processes & Indicator & $\begin{array}{c}\text { Unit of } \\
\text { measurement }\end{array}$ & Description \\
\hline \multirow{3}{*}{ Supply } & $\begin{array}{l}\text { Inventory level in } \\
\text { distribution } \\
\text { center }\end{array}$ & Days & $\begin{array}{l}\text { This indicator represents the level of merchandise inventory expressed in days in the distribution } \\
\text { center and is a function of the volume of daily movement or transfer to stores. From the perspective } \\
\text { of the Abasto process, it measures the effectiveness of planning the supply of suppliers to the } \\
\text { center of distribution. } \\
\text { Calculation: The inventory of the merchandise is divided by the value of its daily trip to stores. }\end{array}$ \\
\hline & Lost sale & $\%$ & $\begin{array}{l}\text { It is the percentage of merchandise that is not in inventory or not available for sale in the store and } \\
\text { that has a daily sales behavior based on statistics. } \\
\text { Calculation: The shortage of each merchandise is divided by the projected daily sale behavior of } \\
\text { each merchandise. }\end{array}$ \\
\hline & $\begin{array}{l}\text { Inventory level in } \\
\text { store }\end{array}$ & Days & $\begin{array}{l}\text { This indicator represents the level of merchandise inventory expressed in days in the store and is } \\
\text { based on the store's sales volume. From the perspective of the Abasto process, it measures the } \\
\text { effectiveness of planning the supply from the distribution center to the store. } \\
\text { Calculation: The inventory of the merchandise in the store is divided by the daily sale value of the } \\
\text { store. }\end{array}$ \\
\hline \multirow{2}{*}{$\begin{array}{l}\text { Merchandise } \\
\text { reception }\end{array}$} & $\begin{array}{l}\text { Compliance with } \\
\text { supplier receipt } \\
\text { program }\end{array}$ & $\%$ & $\begin{array}{l}\text { Level of compliance with the appointment schedule established with providers. } \\
\text { Calculation: The number of arrivals within the window is divided by the number of scheduled } \\
\text { appointments. }\end{array}$ \\
\hline & Fill rate providers & $\%$ & $\begin{array}{l}\text { Level of compliance that is carried with suppliers on the requested merchandise. } \\
\text { Calculation: The quantity of merchandise received is divided by the quantity of merchandise } \\
\text { scheduled to be received. }\end{array}$ \\
\hline \multirow{3}{*}{$\begin{array}{l}\text { Storage of } \\
\text { merchandise }\end{array}$} & $\begin{array}{l}\text { Inventory days in } \\
\text { the distribution } \\
\text { center }\end{array}$ & Days & $\begin{array}{l}\text { This indicator represents the days inventory of merchandise in the distribution center, is based on } \\
\text { the volume of daily trips to stores. } \\
\text { Calculation: The inventory of the merchandise is divided by the value of its daily trip to stores. }\end{array}$ \\
\hline & Product wastage & $\%$ & $\begin{array}{l}\text { This indicator shows the decrease generated in the warehouse due to internal handling and product } \\
\text { obsolescence. } \\
\text { Calculation: The value of the lost merchandise is divided by the value of the total inventory of the } \\
\text { distribution center. }\end{array}$ \\
\hline & $\begin{array}{l}\text { Inventory } \\
\text { rotation }\end{array}$ & $\begin{array}{l}\text { Cycles or } \\
\text { number }\end{array}$ & $\begin{array}{l}\text { This indicator measures the efficiency with which you have the ability to rotate inventory in the } \\
\text { cedis. } \\
\text { Calculation: It is the number of cycles or times that stocks were turned over during a period of } \\
\text { time that can be monthly. }\end{array}$ \\
\hline \multirow{2}{*}{$\begin{array}{l}\text { Order } \\
\text { management }\end{array}$} & Product missing & $\%$ & $\begin{array}{l}\text { This indicator shows products scheduled to be shipped to the store and not in the inventory } \\
\text { available from the distribution center. } \\
\text { Calculation: The total number of missing merchandise is divided by the number of merchandise } \\
\text { scheduled to be shipped to the store. }\end{array}$ \\
\hline & Cycle time & Hours & $\begin{array}{l}\text { This indicator shows the cycle time of an order, it is also known as lead time. } \\
\text { Calculation: It is the time elapsed since the store order is generated until the distribution center } \\
\text { delivers it to the store. }\end{array}$ \\
\hline
\end{tabular}




\begin{tabular}{|c|c|c|c|}
\hline \multirow{2}{*}{$\begin{array}{l}\text { Assortment of } \\
\text { orders }\end{array}$} & $\begin{array}{l}\text { Assortment } \\
\text { productivity }\end{array}$ & Units / hr & $\begin{array}{l}\text { Efficiency indicator that shows the use of resources for the productive tasks of operating personnel } \\
\text { in each work area. } \\
\text { Calculation: The volume supplied (pieces or boxes) is divided by operator per hour of work. There } \\
\text { are three work areas and there may be different productivity units. }\end{array}$ \\
\hline & $\begin{array}{l}\text { Assortment error } \\
\text { rate }\end{array}$ & $\%$ & $\begin{array}{l}\text { Quality indicator that shows the reliability of the assortment of the productive groups. } \\
\text { Calculation: Divide the number of errors in the operating staff assortment by the total assortment } \\
\text { volume per operator. }\end{array}$ \\
\hline $\begin{array}{l}\text { Preparation } \\
\text { and } \\
\text { consolidation } \\
\text { of orders }\end{array}$ & $\begin{array}{l}\text { Productivity in } \\
\text { preparation }\end{array}$ & Units / pallet & $\begin{array}{l}\text { Indicator that shows the performance in the preparation and consolidation of the order prior to } \\
\text { loading it on the platform. It is intended that the integration of orders, both for parts (plastic basket) } \\
\text { and boxes, is of maximum density per palle. } \\
\text { Calculation: Number of packages placed per pallet prepared. }\end{array}$ \\
\hline \multirow{2}{*}{$\begin{array}{l}\text { Loading and } \\
\text { boarding }\end{array}$} & $\begin{array}{l}\text { Productivity } \\
\text { under load }\end{array}$ & Units / truck & $\begin{array}{l}\text { This efficiency indicator aims to measure the load capacity of packages in the transport unit. The } \\
\text { aim is to make the most of the volume of the transport unit. } \\
\text { Calculation: Number of packages loaded per transport unit. }\end{array}$ \\
\hline & $\begin{array}{l}\text { Unit charging } \\
\text { time }\end{array}$ & Hours & $\begin{array}{l}\text { This indicator measures the time the transport unit remains on the loading platform. The objective } \\
\text { is for the unit to be released as soon as possible so that it begins its journey. } \\
\text { Calculation: It is the elapsed time from when the transport unit is assigned to the platform until it } \\
\text { is released to start the journey. }\end{array}$ \\
\hline \multirow{3}{*}{$\begin{array}{l}\text { Delivery of } \\
\text { orders to store }\end{array}$} & $\begin{array}{l}\text { Compliance to } \\
\text { delivery windows }\end{array}$ & $\%$ & $\begin{array}{l}\text { This service indicator reflects arrivals within the expected time period or store delivery window. } \\
\text { Calculation: The number of orders arriving within the assigned time window is divided by the total } \\
\text { number of scheduled orders. }\end{array}$ \\
\hline & Fill rate & $\%$ & $\begin{array}{l}\text { Level of fulfillment of the delivered merchandise vs. the merchandise requested in the store order. } \\
\text { Calculation: The quantity of merchandise delivered to the store is divided by the quantity of } \\
\text { merchandise scheduled to be delivered. }\end{array}$ \\
\hline & $\begin{array}{l}\text { Cycle } \\
\text { deliveries }\end{array}$ & Hours & $\begin{array}{l}\text { This indicator seeks to measure the time it takes for the transport unit on its order delivery route } \\
\text { until it returns to the distribution center to start another cycle. } \\
\text { Calculation: It is the elapsed time from when the unit is released to start an order delivery trip to } \\
\text { stores until it returns to the distribution center. }\end{array}$ \\
\hline
\end{tabular}

Annex 5. Economics indicators of supply chain processes.

\begin{tabular}{|l|l|l|l|}
\hline \multicolumn{1}{|c|}{ Processes } & \multicolumn{1}{|c|}{ Indicator } & $\begin{array}{c}\text { Unit of } \\
\text { measurement }\end{array}$ & Description \\
\hline $\begin{array}{l}\text { Group of processes } \\
\text { inside the distribution } \\
\text { center }\end{array}$ & Warehouse expense & $\begin{array}{l}\text { Represents the expense incurred in the warehouse } \\
\text { operations considering the direct labor related to the } \\
\text { operation. }\end{array}$ \\
\cline { 2 - 5 } & Wastage expense & $\$ /$ package & $\begin{array}{l}\text { It is the expense attributable to the loss of product and } \\
\text { inventory differences in the warehouse. }\end{array}$ \\
\hline $\begin{array}{l}\text { Entrega de pedidos a } \\
\text { tienda }\end{array}$ & Distribution expense & $\$ /$ package & $\begin{array}{l}\text { It is the expense of the distribution and delivery of } \\
\text { merchandise to the store. }\end{array}$ \\
\hline $\begin{array}{l}\text { All processes in the } \\
\text { supply chain }\end{array}$ & Total logistics expenditure & $\$ /$ package & $\begin{array}{l}\text { It is the integral expense of all the key processes that } \\
\text { make up the supply chain of the distribution center. }\end{array}$ \\
\hline
\end{tabular}


Annex 6. Continuity actions matrix of COVID-19.

\begin{tabular}{|c|c|c|c|c|c|c|c|c|c|}
\hline \multirow{2}{*}{$\begin{array}{l}\text { Health } \\
\text { phase }\end{array}$} & \multirow{2}{*}{$\begin{array}{l}\text { Risk } \\
\text { level }\end{array}$} & \multirow{2}{*}{$\begin{array}{l}\text { Capacity } \\
\text { level }\end{array}$} & \multicolumn{2}{|c|}{ Operatives } & \multirow{2}{*}{$\begin{array}{c}\text { Supply } \\
\text { Providers }\end{array}$} & \multicolumn{3}{|c|}{ Service } & \multirow{2}{*}{$\begin{array}{c}\begin{array}{c}\text { Communication } \\
\text { and diffusion }\end{array} \\
\text { Communication }\end{array}$} \\
\hline & & & People & $\begin{array}{l}\text { Facilities and } \\
\text { infraestructure }\end{array}$ & & Merchandise & Stores & $\begin{array}{c}\text { Distribution / } \\
\text { delivery to store }\end{array}$ & \\
\hline $\begin{array}{l}\text { Does no } \\
\text { apply }\end{array}$ & 0 & $\begin{array}{l}\text { Normal } \\
\text { operation } \\
100 \%\end{array}$ & $\begin{array}{l}\text { - } 100 \% \text { operational team } \\
\text { - Recruitment of personnel as a } \\
\text { protection measure against possible } \\
\text { damages due to loss of labor }\end{array}$ & $\begin{array}{l}\text { - Review and evaluation of } \\
\text { risks of manipulation of } \\
\text { equipment and } \\
\text { infrastructure } \\
\text { - Survey of vulnerable } \\
\text { areas to contagion }\end{array}$ & $\begin{array}{l}\text { - Identification of suppliers } \\
\text { with risk of shortage } \\
\bullet \text { Communication and risk } \\
\text { mapping with strategic } \\
\text { suppliers } \\
\text { - Explore alternative vendor } \\
\text { alternatives }\end{array}$ & $\begin{array}{l}\text { - Normal marketing plan } \\
\text { - Normal releases and } \\
\text { promotions } \\
\text { - Local and regional } \\
\text { promotions in the normal way }\end{array}$ & $\begin{array}{l}\text { - } 100 \% \text { supply of stores } \\
\text { - Monitoring of stores closed } \\
\text { due to contingencies }\end{array}$ & \multirow{2}{*}{$\begin{array}{l}\text { - Strengthening of } \\
\text { the transport fleet } \\
\text { (own and } \\
\text { contracted) } \\
\text { - Routing planning } \\
\text { with sequential time } \\
\text { windows }\end{array}$} & \multirow{5}{*}{$\begin{array}{l} \\
\text { - Activation of the } \\
\text { Incident } \\
\text { Management and } \\
\text { Crisis Resolution } \\
\text { Committee (MIRC) } \\
\text { - Establishment of } \\
\text { the crisis action } \\
\text { plan } \\
\text { - Establishment of } \\
\text { communication } \\
\text { roles in the } \\
\text { management team } \\
\text { - Towards the } \\
\text { staff } \\
\text { - Towards the } \\
\text { client } \\
\text { - Towards the } \\
\text { General Directorate } \\
\text { - Towards } \\
\text { authorities and } \\
\text { government } \\
\text { - With the press } \\
\text { and social media } \\
\bullet \text { Carry out a } \\
\text { follow-up session to } \\
\text { the operation and } \\
\text { review each } \\
\text { element of the } \\
\text { contingency matrix }\end{array}$} \\
\hline 1 & 1 & 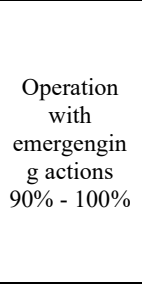 & $\begin{array}{l}\text { - Assignment of personnel to the } \\
\text { operational workforce by } 10 \% \\
\text { - Identification of areas that require } \\
\text { working overtime } \\
\text { - Isolation for personnel classified as } \\
\text { vulnerable group } \\
\text { - Activation of health filters to } \\
\text { identify symptoms in the staff }\end{array}$ & $\begin{array}{l}\text { - Installation of health and } \\
\text { safety measures such as } \\
\text { health filters } \\
\text { - Restriction of access to } \\
\text { confined areas or without } \\
\text { adequate ventilation } \\
\text { - Cancellation of meeting } \\
\text { places that do not comply } \\
\text { with the distance measures }\end{array}$ & $\begin{array}{l}\text { - Establish a supply plan for } \\
\text { items considered to be in high } \\
\text { demand due to contingencies } \\
\text { - Establish prioritization } \\
\text { strategy with merchandise } \\
\text { categories (privilege suppliers } \\
\text { of basic products) } \\
\text { - Activation of alternative } \\
\text { providers and privilege } \\
\text { regional alternatives } \\
\end{array}$ & $\begin{array}{l}\text { - Normal marketing plan } \\
\text { - Normal releases and } \\
\text { promotions } \\
\text { - Local and regional } \\
\text { promotions in the normal way } \\
\text { - Identification of the articles } \\
\text { considered essential to } \\
\text { prioritize their supply from } \\
\text { suppliers }\end{array}$ & $\begin{array}{l}\text { - } 100 \% \text { supply of stores } \\
\text { - Monitoring of stores closed } \\
\text { due to contingencies } \\
\text { - Monitoring of rejection of } \\
\text { deliveries to store by } \\
\text { contingency }\end{array}$ & & \\
\hline \multirow[t]{2}{*}{2} & 2 & $\begin{array}{c}\text { Operational } \\
\text { performance } \\
70 \%-90 \%\end{array}$ & $\begin{array}{l}\text { - Exploration and activation of } \\
\text { operating schedules, working days } \\
\text { and shift duration } \\
\text { - Activation of shifts on non- } \\
\text { working days } \\
\text { - Keep staff from vulnerable groups } \\
\text { in isolation } \\
\text { - Maintain health filters to identify } \\
\text { symptoms in staff }\end{array}$ & $\begin{array}{l}\text { - Installation of health and } \\
\text { safety measures such as } \\
\text { health filters } \\
\text { - Restriction of access to } \\
\text { confined areas or without } \\
\text { adequate ventilation } \\
\text { - Cancellation of meeting } \\
\text { places that do not comply } \\
\text { with the distance measures } \\
\text { - Installation of physical } \\
\text { barriers in work areas to } \\
\text { avoid the risk of contagion }\end{array}$ & $\begin{array}{l}\text { - Generation of advance } \\
\text { purchases for items classified } \\
\text { as essential } \\
\text { - Prioritization of supplier } \\
\text { receipts } \\
\text { - Consider the exchange of } \\
\text { merchandise between } \\
\text { distribution centers and stores } \\
\text { (optimally distribute } \\
\text { shortages) } \\
\text { - Activation of alternative } \\
\text { providers and privilege of } \\
\text { regional alternatives }\end{array}$ & $\begin{array}{l}\text { - Adjusted marketing plan } \\
\text { and according to merchandise } \\
\text { availability } \\
\text { - Prioritize the marketing of } \\
\text { essential contingency items, } \\
\text { such as food and perishables, } \\
\text { cleaning and hygiene } \\
\text { - Management with capacity } \\
\text { planning, inventory } \\
\text { replacement adjust purchases } \\
\text { according to demand and } \\
\text { capacity level of the } \\
\text { distribution center }\end{array}$ & $\begin{array}{l}\text { - Monitoring of stores closed } \\
\text { due to contingencies } \\
\text { - } 100 \% \text { supply of stores } \\
\text { - Monitoring of rejection of } \\
\text { deliveries due to contingencies } \\
\text { - Decrease in the frequency of } \\
\text { delivery of orders to stores } \\
\text { - Financial analysis that favors } \\
\text { sending orders to the best- } \\
\text { selling stores }\end{array}$ & $\begin{array}{l}\bullet \text { Extension of } \\
\text { distribution days } \\
\text { - Modify daily } \\
\text { delivery plan to a } \\
\text { less frequent one }\end{array}$ & \\
\hline & 3 & $\begin{array}{c}\text { Operational } \\
\text { performance } \\
50 \%-70 \%\end{array}$ & $\begin{array}{l}\text { - Balancing of operating loads } \\
\text { according to staff availability, } \\
\text { activation of extra shifts according to } \\
\text { availability } \\
\text { - Keep staff from vulnerable groups } \\
\text { in isolation } \\
\text { - Staff working remotely (for those } \\
\text { who apply the scheme) } \\
\text { - Strengthening of established health } \\
\text { filters, identification of symptoms in } \\
\text { personnel }\end{array}$ & \multirow{2}{*}{$\begin{array}{l}\text { - Installation of health and } \\
\text { safety measures such as } \\
\text { health filters, sanitizing } \\
\text { mats, sanitization } \\
\text { application with authorized } \\
\text { cleaning fluids } \\
\text { - Restriction of access to } \\
\text { confined areas or without } \\
\text { adequate ventilation } \\
\text { - Cancellation of meeting } \\
\text { places that do not comply } \\
\text { with the distance measures } \\
\text { - Installation of physical } \\
\text { barriers in work areas to } \\
\text { avoid the risk of contagion }\end{array}$} & \multirow{2}{*}{$\begin{array}{l}\text { - Generation of advance } \\
\text { purchases for items classified } \\
\text { as essential } \\
\text { - Prioritization of the receipt } \\
\text { of strategic merchandise } \\
\text { suppliers } \\
\text { - Consider the exchange of } \\
\text { merchandise between } \\
\text { distribution centers and stores } \\
\text { (optimally distribute } \\
\text { shortages) } \\
\text { - Activation of alternative } \\
\text { providers and privilege } \\
\text { regional alternatives } \\
\text { - Daily communication on } \\
\text { the operational continuity of } \\
\text { suppliers based on the priority } \\
\text { classification of their products } \\
\text { - Evaluate the collection of } \\
\text { merchandise at the supplier's } \\
\text { facilities }\end{array}$} & \multirow{2}{*}{$\begin{array}{l}\text { - Prioritize the marketing of } \\
\text { essential contingency items, } \\
\text { such as food and perishables, } \\
\text { cleaning and hygiene } \\
\text { - Management with capacity } \\
\text { planning, inventory } \\
\text { replacement adjust purchases } \\
\text { according to demand and } \\
\text { capacity level of the } \\
\text { distribution center } \\
\text { - Carry out financial analysis } \\
\text { to privilege the articles that } \\
\text { provide the greatest economic } \\
\text { benefit to the organization. } \\
\text { - Exchange of merchandise } \\
\text { between operating units and } \\
\text { stores }\end{array}$} & $\begin{array}{l}\text { - Validation of stores that } \\
\text { remain open and capable of } \\
\text { receiving merchandise } \\
\text { - Supply to stores classified as } \\
\text { private based on sale } \\
\text { - Decrease in the frequency of } \\
\text { delivery of orders to the store }\end{array}$ & \multirow{2}{*}{$\begin{array}{l}\text { - Extension of } \\
\text { delivery days to } \\
\text { store } \\
\bullet \text { Balancing } \\
\text { operators in } \\
\text { deliveries } 24 \text { hours } \\
\text { - Decrease the } \\
\text { frequency of } \\
\text { delivery of orders } \\
\text { to the store } \\
\text { - Perform dynamic } \\
\text { routing with } \\
\text { priority stores and } \\
\text { - Eliminate } \\
\text { restriction of order } \\
\text { delivery windows }\end{array}$} & \\
\hline 3 & 4 & $\begin{array}{c}\text { Operational } \\
\text { performance } \\
30 \%-50 \%\end{array}$ & $\begin{array}{l}\text { - Balancing of operating loads } \\
\text { according to staff availability, } \\
\text { activation of extra shifts according to } \\
\text { availability } \\
\text { - Keep staff from vulnerable groups } \\
\text { in isolation } \\
\text { - Staff working remotely (for those } \\
\text { who apply the scheme) } \\
\text { - Strengthening of established health } \\
\text { filters, identification of symptoms in } \\
\text { personnel }\end{array}$ & & & & $\begin{array}{l}\text { - Validation of stores that } \\
\text { remain open and capable of } \\
\text { receiving merchandise } \\
\text { - Monitoring of rejection of } \\
\text { deliveries due to contingencies } \\
\text { - Supply of stores that remain } \\
\text { open and classified as high sales } \\
\text { - Delivery of orders according } \\
\text { to availability and receipt } \\
\text { capacity }\end{array}$ & & \\
\hline
\end{tabular}

